\title{
BADAN ARBITRASE SYARI'AH NASIONAL (BASYARNAS) MENYELESAIKAN SENGKETA SECARA ADIL DAN CEPAT
}

\author{
SANAWIAH \\ Dosen Fakultas Agama Islam Universitas Muhammadiyah Palangkaraya
}

\begin{abstract}
ABSTRAK
Penelitian ini bertujuan mengetahui Pengertian, sejarah, Dasar Hukum Badan Arbitrase Syari'ah Nasional dan Badan Arbitrase Nasional Syari'ah Nasional Dapat Menyelesaikan Sengketa Secara Adil dan Cepat ; Metode Penelitian; metode yang di gunakan adalah metode yuridis Normative mengingat bahwa penelitian ini menekankan pada data skundir yakni dengan mempelajari dan mengkaji azaas-azas, bahanbahan dan kaidah-kaidah hukum positifnya yang dari bahan-bahan kepustakaan yang ada dalam perundang-undangan, data dalam penelitian dikumpulkan melalui Observasi.

Hasil dari penelitian ini, penyelesaian melalui Arbitrase diyakini memiliki keunggulan-keunggulan dibadingkan dengan jalur pengadilan, tetapi penyelesaian melalui Arbitrase juga masih memiliki kelemahankelemahan.
\end{abstract}

\section{PENDAHULUAN}

Menyelesaikan perselisihan/Sengketa-

Sengketa keperdataan dengan perinsip mengutamakan usaha-usaha perdamaian/islah, Badan Arbetrase Syari'ah Nasional (BASYARNAS) berwenang menyelesaikan secara adil dan cepat Sengketa muamalah (perdata) yang timbul dalam bidang perdagangan, keuangan, industri, jasa dan lain-lain yang menurut hukum dan peraturan perundangundangan dikuasai sepenuhnya oleh pihak yang berSengketa, dan para pihak sepakat secara tertulis untuk menyerahkan penyelesaiannya kepada BASYARNAS sesuai dengan prosedur BASYARNAS.

Memberikan pendapat yang mengikat atas permintaan para pihak tanpa adanya suatu Sengketa mengenai persoalan berkenaan dengan suatu perjanjian, Mekanisme Oprasional Badan Arbetrase Syari'ah Nasional (BASYARNAS) Mempunyai prosedur yang memuat ketentuanketentuan antara lain: permohonan untuk mengadakan arbiter, acara pemeriksaan, perdamaian, pembuktian dan saksi/ahli, berakhirnya pemeriksaan, pengambilan putusan, perbaikan putusan, pembatalan putusan, pendaftaran putusan, pelaksanaan putusan (eksekusi), biaya arbitrase

Persengketaan yang terjadi seperti tidak memenuhi kewajiban, baik itu jangka pendik maupun jangka panjang seperti tidak membayar pada saat jatuh tempo, Kewajiban-kewajiban nasabah kepada Bank, terutama nasabahnasabah besar, apabila keputusan Basyarnas belum final bagi para pihak yang berSengketa, merika biasanya melakukan banding ke pengadilan agama. menurut prof. Mariam Darus Badrulzaman, lahirnya Badan Arbitrasi Syari'ah Nasional sangat tepat karena melalui Badan Arbitrase tersebut, Sengketa-Sengketa bisnis yang oprasionalnya menggunakan hukum islam dapat di selesaikan mempergunakan dengan mempergunakan hukum islam. 
Adanya Badan Arbitrase Syari'ah sebagai suatu lembaga permanen, berfungsi untuk menyelasaikan kemungkinan terjadinya Sengketa perdata diantara bank-bank Syari'ah dengan para nasabahnya atau pengguna jasa mereka pada khususnya dan antara sesama umat Islam yang melakukan hubungan - hubungan keperdataan yang menjadi syarat Islam sebagai dasarnya pada umumnya adalah merupakan suatu kebutuhan yang sungguh-sungguh nyata.

Adapun Arbitrase dianggap memiliki beberapa keunggulan dibandingkan dengan cara litigasi, oleh karena itu dalam praktek para pelaku bisnis dan dunia usaha ada kecendrungan untuk memilih penyelesaian Sengketa melalui arbitrase.

Pengertian, Sejarah, Dasar Hukum Badan Arbitrase Syari'ah Nasional

\section{Pengertian Badan Arbetrasi Syari'ah Nasional}

- Pengertian Arbitrase suatu kekuasaan untuk menyelesaikan sesuatu menurut kebijakan ( $R$. Subekti), atau satu cara menyelesaikan Sengketa yang jauh dianggap lebih baik daripada penyelesaikan melalui saluransaluran biasa (sudargao Gautama).

- Pengertian Syari'ah jalan lurus yang harus di ikuti setiap muslim (M. Daud Ali), atau ketentuan-ketentuan hukum yang berhubungan dengan perbuatan manusia (Abdullah Yusuf Ali).

- Arbitrae Syari'ah penunjukan secara sukarela dari dua orang yang berSengketa akan seseorang yang mereka percaya untuk menyelesaikan Sengketa (Abdul Karim Zaidan) atau suatu penyelesaian Sengketa yang dilakukan oleh hakam yang dipilih atau di tunjuk secara sukarela oleh dua orang yang berSengketa untuk mengakhiri Sengketa antara mereka dan dua belah pihak akan menaati penyelesaian oleh hakam/para hakam yang mereka tunjuk itu (Satria Effendi M. Zen).

\section{Sejarah Arbitrase Syari'ah dan Arbitrase Syari'ah di Indonesia}

Nama Abu Sjureich atau Abu al-Hakam pada masa Nabi Muhammad SAW, di hormati karena kebijaksanaannya setiap perselisihan anggota masyarakat yang di ajukan kepadanya. Kemudian pada masa khalifah Umar bin khattab sistem hakam atau arbitrase mengalami perkembangan seiring dengan pembenahan lembaga peradilan, dan tersusun dalam risalah al- Qadla yang salah satu isinya adalah pengukuhan terhadap kedudukan arbitrase (A. Rosyadi, Ngatino)

- Arbitrase Syari'ah di Indonesia Rapat Kerja Nasional (RAKERNAS) MUI tahun 1992, Hartono Marjono, SH. Ditugasi memaparkan makalahnya tentang Arbitrase berdasarkan Sari'ah Islam yang kemudian mendapat sanbutan baik dari kalangan dari kalangan peserta dan kemudian kemudian di rekomendasikan untuk di tindak lanjuti oleh MUI. Pada tanggal 22 april 1992, Dewan Pimpinan MUI mengundang para praktisi hukum termasuk dari kalangan perguruan tinggi guna bertukar pikiran tentang perlu tidaknya dibentuk dibentuk arbitrase Islam.

Pada rapat selanjutnya tanggal 2 mei 1992, di undang juga wakil dari bank muamalat Indonesia dan untuk selanjutnya di bentuk tim kecil guna mempersiapkan bahan-bahan kajian untuk kemungkinannya membentuk badan arbitrase Islam. Demikian selanjutnya dalam rakernas MUI 24-27 November 1992, juga diputuskan bahwa sehubungan dengan rencana 
pendirian lembaga arbitrase muamalat, agar MUI segra merialisasikan.

MUI dengan SK. No. Kep. 392/MUI/V/1992, tanggal 4 mei 1992,, telah membentuk kelompok kerja pembentukan badan arbitrase hukum Islam, yang terdiri dari :

Nama Sumber : Prof. KH. Ali Yafie, Prof KH. Husen, LML, H. Andi Lolo tonang, S.H, H. Hartono Mardjono, S.H, Jimly Asshiddiqie, SH, $\mathrm{MH}$.

\section{Dasar Hukum Arbitrase Syari'ah}

\section{Al- Qur'an}

a. Surat Al- Hujurat ayat 9

"Dan kalau ada dua golongan dari mereka yang beriman itu berperang hendaklah kamu damaikan antara keduanya! Tapi kalau yang satu melanggar perjanjian terhadap yang lain, hendaklah yang melanggar perjanjian itu kamu perangi sampai surut kembali pada perintah Allah. Kalau dia Telah surut, damaikanlah antara keduanya menurut keadilan, dan hendaklah kami berlaku adil; Sesungguhnya Allah mencintai orang-orang yang berlaku adil"

b. Surat An- Nisa ayat 35

"Dan jika kamu khawatirkan ada persengketaan antara keduanya, Maka kirimlah seorang hakam dari keluarga laki-laki dan seorang hakam dari perempuan. Jika kedua orang hakam itu bermaksud mengadakan perbaikan, niscaya Allah memberi taufik kepada suami-istri itu. Sesungguhnya Allah Maha mengetahui lagi Maha Mengenal'

\section{As- Sunnah}

Hadits riwayat An-Nisa'i menceritakan dialog Rasulullah dengan Abu Syureih. Rasullah bertanya kepada Abu Syureih:" kenapa kamu dipanggil abu Al- Hakam? Abu Syurein
Menjawab:" sesungguknya apabila kaumku bertengkar, mereka datang kepadaku, meminta aku menyelesaikannya, dan mereka rela dengan keputusanku itu" Mendengar jawaban Abu Syureih itu Rasulullah berkata "alngkah baiknya perbuatan itu" Demikian Rasulullah membenarkan bahkan memuji perbuatan Abu Syureih, Sunnah yang demikian disebut Sunnah tak Taqririyah ljma'

Banyak riwayat menunjukan bahwa para ulama dan sahabat Rasulullah sepakat Rasulullah (ljma') membenarkan segkita dengan cara Arbitrase. Misalnya, di riwayatkan tatkala Umar bin Khattab hendak membeli seekor kuda. Pada saat umar menunggang kuda itu untuk di coba, kaki kuda itu patah. Umar hendak mengembalikan kepada pemiliknya. Pemilik kuda itu menolak. Umar berkata: "Baiklah, tunjuklah seseorang yang kamu percaya untuk menjadi hakam (Arbiter) antara kita berdua. Pemilik kuda itu berkata: "Aku rela Abu Syureih untuk menjadi hakam". Maka dengan menyerahkan penyelesaian Sengketa itu pada Abu Syureih. Abu Syureih (hakam) yang dipilih itu memutuskan bahwa umar harus mengambil dan membayar harga kuda itu. Abu Syureih berkata kepada Umar bin Khattab:"Ambilah apa yang kamu beli (dan bayar harganya) atau kembalikan kepada pemilik apa yang telah kamu ambil seperti semula tanpa cacat" Umar menerima baik putusan itu.

\section{Undang-Undang No. 30 Tahun 1999 tentang Arbitrase dan Alternatif Penyelesaian Sengketa}

Arbitrase menurut Undang-undang no 30 Tahun1999 adalah cara penyelesaian Sengketa perdata diluar pengadilan umum, sedangkan lembaga arbitrase adalah badan yang dipilih oleh 
para pihak yang bersangketa untuk memberikan putusan mengenai Sengketa itu.

Badan Arbitrase Syariah Nasional adalah lembaga arbitrase sebagaimana dimaksud UU No. 30 Tahun 1999. SK Dewan Pimpinan MUI No. Kep- 09/MUI/XII/2003 Tanggal 30 Syawwal 1424 H (24 Desember 2003) tentang Badan Arbitrase Syari'ah Nasional. Fatwa DSN-MUI, Semua fatwa Dewan Syariah Nasional Majelis Ulama Indonesia (DSN-MUI) perihal hubungan muamalah (perdata) senantiasa diakhiri dengan ketentuan:" Jika salah seorang tidak melakukan kewajibannya atau terjadi perselisihan 'diantara kedua belah pihak, maka penyelesaiannya dilakukan melalui Badan Arbitrase Syari'ah setelah tidak tercapai kesepakatan melalui musyawarah.(Lihat Fatwa No 05 tentang, jual beli saham, Fatwa No,06 tentang jual beli istishna, Fatwa No 7 tentang pembiayaan mudharabah, Fatwa No. 08 tentang pembiayaan musyarakah, dan seterusnya.

\section{Dengan Badan Arbitrase Nasional Syariah Nasional Dapat Menyelesaikan Sengketa Secara Adil dan Cepat ;}

Contoh perkara yang dapat diselesaikan oleh Basyarnas adalah sejak berdirinya pada tahun 1993 sampai dengan tahun 2006 baru menyelesaikan perkara sebanyak 14 perkara dari berbagai perkara telah diajuka. Adapun banyaknya perkara yang di tolak, karena perkara kurang memenuhi persyaratan, dari perkara tersebut yang paling banyak terjadi adalah pada akad mudharabah dan murabahah dengan sistem profit and loss sharing.

Bogor Badan Arbitrase Syariah Nasional (Basyarnas) telah menyelesaikan 17 sengketa perbankan syariah tahun 1997-2010. Kasus tersebut terjadi karena belum lengkapnya perangkat hukum yang mengatur perbankan syariah serta ketidak pahaman masyarakat mengenai peraturan syariah ini.

"Sampai kini, ada 19 kasus sengketa perbankan syariah yang ditangani Basyarnas, yang sebagian besar dimenangkan bank. Mayoritas kasus itu dilaporkan bank," kata Ketua Basyarnas Yudo Paripurno saat seminar mengenai kajian penyelesaian sengketa utang-piutang (muamalah) lembaga keuangan syariah di Bogor, Senin (27/9).

Basyarnas merupakan lembaga arbitrase nasional satu-satunya yang menerapkan hukum Islam (syariah) dan berperan menyelesaikan seluruh sengketa muamalah. Sengketa perbankan syariah di Indonesia biasanya diselesaikan melalui lembaga ini.

"Perkara yang timbul antara lain soal pembiayaan amudharabah (bagi hasil), al bai bithaman ajil (untuk pembelian barang), al mudharabah muqqayadah (investasi khusus), serta klaim asuransi barang terkait surat perjanjian angkutan,".

Yudo menuturkan, belum semua permasalahan perbankan syariah dilaporkan ke Basyarnas, karena masyarakat kurang mengahui mengenai penyelesaian sengketa syariah, termasuk fungsi Basyarnas. Hingga kini, masyarakat lebih banyak menyelesaikan sengketa melalui jalur pengadilan.

"Padahal, lembaga arbitrase memiliki kelebihan dibanding pengadilan, karena proses pemeriksaan sederhana, tertutup, cepat, dan bermartabat,". Untuk itu, dalam waktu dekat. Basyarnas mengadakan sosialisasi mengenai lembaga arbitrase syariah serta cara penyelesaian sengketa perbankan syariah. 
Arbitrase merupakan cara penyelesaian suatu Sengketa perdata di luar peradilan yang diluar peradilan umum yang didasarkan pada perjanjian arbitrase yang dibuat secara tertulis oleh para pihak yang berSengketa (Lihat Pasal 1 angka 1 UU No. 30 Tahun 1999).

Arbitrase dianggap memiliki beberapa keunggulan dibandingkan dengan cara litigasi, oleh karena itu dalam praktek para pelaku bisnis dan dunia usaha ada kecendrunganuntuk memilih penyelesaian Sengketa melalui arbitrase.

Adapun beberepa keunggulan antara lain

1) Dijamin kerahasiaan Sengketa para pihak;

2) Dapat di hindari kelambatan yang diakibatkan karena hal procedural dan administrastrative

3) Para pihak dapat memilih arbiter yang menurut keyakinannya mempunyai pengetahuan, pengalaman serta latar belakang yang cukup mengenai maalah yang diSengketakan, jujur dan adil.

4) Para pihak dapat menentukan pilihan hukum untuk menyelesaikan masalahnya serta proses dan tempat penyelenggaraan arbitrase dan

5) Putus arbitrase merupakan putusan yang mengikat para pihak dan dengan melalui tata cara (prosedur) sederhana saja ataupun langsung dapat dilaksanaan.

Michael B. Metzger mengemukakan pendapat keuntungan penyelesaian Sengketa melalui arbitrase ini :

"As compared with the court syistem, the main advantages clained for arbitration are :

1. Quicker resolution of disputes

2. Lower costs in time and mony to the parties, and

3. The availability of professional who are often expert in the subject matter of dispute".
Pada kenyataannya apa yang disebutkan di atas, tidak semuanya benar, sebab di negaranegara tertentu proses peradilan dapat lebih cepat daripada proses arbitrase. Di antara kelebihan arbitrase terhadap pengadilan adalah sifat kerahasiaannya, karena keputusannya tidak dipublikasikan. Namun demikian, penyelesaian sengketa melalui arbitrase masih lebih diminati daripada litigasi, terutama untuk kontrak bisnis atau dagang yang bersifat internasional. Sifat rahasia arbitrase dapat melindungi para pihak dari hal-hal yang tidak diinginkan atau yang merugikan akibat penyingkapan informasi bisnis kepada umum. Penyelesaian melalui arbitrase diyakini memiliki keunggulan-keunggulan dibandingkan dengan jalur pengadilan, tetapi penyelesaian melalui Arbitrase juga memiliki kelemahankelemahan. Beberapa kelemahan dari Arbitrase dan ADR adalah :

a. Arbitrase belum dikenal secara luas, baik oleh masyarakat awam, maupun masyarakat bisnis, bahkan oleh masyarakat akademis sendiri. Sebagai contoh masyarakat masih banyak yang belum mengetahui keberadaan dan kiprah dari lembaga-lembaga seperti BANI, BASYARNAS dan P3BI.

b. Masyarakat belum menaruh kepercayaan yang memadai, sehingga enggan memasukkan perkaranya kepada lembaga-lembaga Arbitrase. Hal ini dapat dilihat dari sedikitnya perkara yang diajukan dan diselesaikan melalui lembaga-lembaga Arbitrase yang ada.

c. Lembaga Arbitrase dan ADR tidak mempunyai daya paksa atau kewenangan melakukan eksekusi putusannya.

d. Kurangnya kepatuhan para pihak terhadap hasil-hasil penyelesaian yang dicapai dalam 
Arbitrase, sehingga mereka seringkali mengingkari dengan berbagai cara, baik dengan teknik mengulur-ulur waktu, perlawanan, gugatan pembatalan dan sebagainya.

e. Kurangnya para pihak memegang etika bisnis. Sebagai suatu mekanisme extra judicial, Arbitrase hanya dapat bertumpu di atas etika bisnis, seperti kejujuran dan kewajaran.

\section{KESIMPULAN}

Badan Arbitrase Syari'ah Nasional adalah untuk menyelesaikan berbagai sengketa dalam sektor ekonomi syari'ah belum sepenuhnya terlaksana dikarenakan kekurangan SDM serta finansial.

Lingkup kewenangannya ialah dalam bidang arbitrase dan masih terbatas dalam lingkup perbankan syaelum riah secara umum, dan akan dikembangkan dalam bidang jasa dan industri sehingga Basyarnas mempunyai kontribusi yang besar untuk masyarakat.

Mekanisme operasionalnya belum terorganisir seperti kepengurusan cabang sama dengan kepengurusan pusat. Contoh perkara yang diselesaikan ialah perkara-perkara besar (nasabah besar).

\section{SARAN}

1. Kepada pemerintah sosialisasi keberadaan Arbitrase lebih di poblikasikan secara luas kepada masyarakat

2. Badan Arbitrasi Syari'ah Nasional sebaiknya ada di Daerah-Daerah dan secepatnya di bentuk cabang-cabangnya

3. Badan Arbitrasi Syari'ah Nasional sebagai lembaga permanen dalam menyelesaikan Sengketa menjadi kepercayaan masyarakat harus selalu menjaga amanah.

\section{DAFTAR PUSTAKA}

Badan Arbitrase Syariah Nasional, Profil dan Prosedur, BASYARNAS. Artikel 2006.

Djauhari, Achmad, 2006. Arbitrase Syari'ah di Indonesia, BASYARNAS.

Jamin, Mohammad.1995. Mekanisme Alternatif Penyelesaian Sengketa. Surakarta : Universitas Sebelas Maret (UNS)

Widjaja, Gunawa. 2001. Alternatif Penyelesaian Sengketa . PT Raja Grafindo Persada. Jakarta

http://hndwibowo.blogspot.com/2008/06/badanarbitrase-syariah-nasional.html

http://id.shvoong.com/law-and-politics/1908998keunggulan-dan-kelemahan-arbitrase/

http://bataviase.co.id/node/397004 

